\title{
Application of Simple Average Weighting Optimization Method in the Selection of Best Desktop Computer Model
}

\author{
Soupayan Mitra, Shankha Shubhra Goswami* \\ Department of Mechanical Engineering, Jalpaiguri Government Engineering College, West Bengal
}

* Corresponding Author email: shankhashubhragoswami@gmail.com

Article History

Received: 05 June 2019

Revised: 04 July 2019

Accepted: 22 July 2019

Published: 22 July 2019

Student(s)

- Shankha Shubhra Goswami

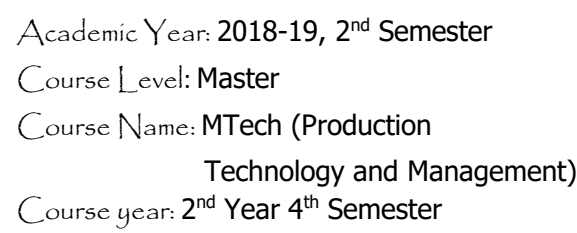

- Soupayan Mitra

\section{ABSTRA C T}

Multi-Criteria Decision Making (MCDM) is one of the most emerging concepts in today's world which enables a decision maker to select the best strategies among different available alternatives. MCDM technique helps to remove the biasness and confusion while selecting a product or process. In recent few years different MCDM methodologies finds wide area of applications in industries as well as in our daily life. In this paper, such one type of application is broadly described. One example is taken from our daily life, which is generally faced by most of the students while purchasing a desktop computer. The main objective of this paper is to select the best desktop computer models among five different models actual available in the market having different configurations. For this analysis, 100 computer users have been surveyed to know their relative preferences and choices, which of the computer specifications is most important to them. For this present analysis few numbers of criteria have been considered and also there are number of sub-criteria within each criterion (for example, the processor may be different for different models like I3, I5, I7 etc.). The MCDM methodology which is adopted for this selection process is known as Simple Average Weighting (SAW) method.

Keywords: Multi-Criteria Decision Making, Simple Average Weighting, Desktop Computers, Criteria, Sub-Criteria

\section{Introduction}

Computers now a days became an essential gadget in everyday life. In this ever-developing world, computers make our work faster and easier which makes it more demanding electronic devices [1]-[2]. There are lots of computer models available in the market from various brands with different configurations which makes the buyers more confusing which is the best model to buy according to their need. This paper aims to remove this type of confusion from the buyer's mind and provides a perfect solution to this type of problem through MCDM methodology [1]-[2]. There are different types of MCDM methods like AHP (Analytic Hierarchy Process) [3]-[4], TOPSIS [5-6], PROMETHEE [7], AHP-FUZZY [8] etc. which can also be applied to select the best alternatives. 
The present investigation involves the selection of the best desktop computer model by simple average weighting method [2] from 5 available models in the market (shown in Table 1) based on the market survey of 100 people having 5 different criteria (i.e. Processor, Hard Disk Capacity, Screen Size, RAM, Brand) and each criteria have their own sub-criteria.

Table 1: Five Desktop Models Available in the Market that are Considered for this Analysis

\begin{tabular}{|c|c|c|c|c|c|}
\hline Models & Processor & Brand & Screen Size & $\begin{array}{c}\text { Hard Disk } \\
\text { Capacity }\end{array}$ & RAM \\
\hline Model 1 & I3 & Samsung & 23.8 Inch & $2 \mathrm{~TB}$ & $8 \mathrm{~GB}$ \\
\hline Model 2 & I3 & Dell & 21.5 Inch & $1 \mathrm{~TB}$ & $4 \mathrm{~GB}$ \\
\hline Model 3 & I5 & BenQ & 18.5 Inch & $512 \mathrm{~GB}$ & $4 \mathrm{~GB}$ \\
\hline Model 4 & I7 & HP & 18.5 Inch & $1 \mathrm{~TB}$ & $16 \mathrm{~GB}$ \\
\hline Model 5 & I5 & AOC & 15.6 Inch & $1 \mathrm{~TB}$ & $4 \mathrm{~GB}$ \\
\hline
\end{tabular}

The above mentioned 5 most important criteria is considered for this analysis which the buyers actually noticed while purchasing a desktop computer. Obviously other criteria can also be considered e.g. graphics card, screen resolution etc. [1], [6]. for this analysis but it varies from researchers to researchers which criteria's is to be considered. The main aim of this paper is to select the best desktop model among 5 models actual available in the market. Previously different researchers adopted different MCDM methods [1]-[2] and applied in many fields such as water management, energy management, telecommunication industry, automobile industry etc. [6]. but very few research works have been reported of applying MCDM techniques in our daily life for the selection of best process and strategies, hence there is a scope of implementing multi-criteria decision making for the selection of household appliances and electronics devices associated with our daily life.

\section{Literature Review}

For the past few years several researchers [9]-[12] applied different MCDM methodology in various field of applications such as industrial sector, private sector, energy management [13]-[15] waste management, environmental management, supply chain management, supplier selection [16-17] etc. and also receives good outcome results which makes the MCDM methodology more popular among the researchers [14]. At present most of the researchers mainly focuses on the area of industrial applications. Afshari et al. [18] applied simple average weighting method for the selection of personnel in Iran. Most of the researchers generally adopted the hybrid MCDM process for their analysis since it provides more accurate results [12], [9-10]. AHP can be integrated with SAW, Mitra et al. [2] adopted AHP-SAW technique for the selection of the best laptop model, this paper introduces the calculation of the weightages of the main criteria by AHP methodology and further using these weightages in the SAW analysis and also Mitra et al. [1] adopted the integrated AHP-TOPSIS methodology in their paper for the selection of the best desktop computer model. Some researchers also implemented Fuzzy [19]-[22] concept along with AHP, TOPSIS and SAW for the decision-making process. Deni et al. [23] implemented Fuzzy -SAW (FSAW) [22] for selecting high achieving student in faculty level, in this research paper six criteria is being considered and based on this criteria's the whole analysis is carried out. Gupta and Gupta [24] compares SAW, FSAW, Fuzzy-TOPSIS [22] for vendors rating. From the analysis it is found that Fuzzy-TOPSIS is more effective in rating the vendors more accurately and more precisely. Kumar et al. [25] applied FSAW in Punj Lyord plant Gwalior (India) for the selection of an appropriate maintenance strategy for material handling purposes.

\section{Theoretical Analysis}

This paper aims to select the best desktop model by the application of the integrated AHP-SAW [2] methodology. At first Analytic Hierarchy Process (AHP) [3] is applied to find out the weightages of the main criteria [26] and then further using these weightages in the SAW thus making this process a hybrid 
Mitra et al., Adv. J. Grad. Res.; Vol. 6, Issue 1, pp: 60-68, July 2019

MCDM process. SAW [27]-[28] is one of the most widely used MCDM method since it is very easy to apply and due to its simplicity in operation. The step by step process of SAW is described in detail below [18].

Step 1: Based on the market survey of the people, create a pair-wise comparison matrix of $\mathrm{n} \times \mathrm{n}$ for the main criteria according to Saaty's pair-wise comparison scale [3]-[4] shown in Table 2. In this case $\mathrm{n}=5$, since 5 criteria is considered for this present analysis

$$
A\left(n_{i} \times n_{j}\right)=\left[\begin{array}{ccccc}
a_{11} & a_{12} & a_{13} & \ldots & a_{1 n} \\
a_{21} & a_{22} & a_{23} & \ldots & a_{2 n} \\
a_{31} & a_{32} & a_{33} & \ldots & a_{3 n} \\
\ldots & \ldots & \ldots & \ldots & \ldots \\
a_{n 1} & a_{n 2} & a_{n 3} & \ldots & a_{n n}
\end{array}\right]
$$

Table 2: Saaty's 9 Pair-Wise Comparison Scale [3]

\begin{tabular}{|c|c|}
\hline $\begin{array}{c}\text { Saaty's pair wise } \\
\text { comparison scale }\end{array}$ & $\begin{array}{c}\text { Compare factor } \\
\text { of } \mathbf{i} \boldsymbol{\&} \mathbf{j}\end{array}$ \\
\hline $\mathbf{1}$ & Equal importance \\
\hline $\mathbf{3}$ & Moderate importance \\
\hline $\mathbf{5}$ & Strong importance \\
\hline $\mathbf{7}$ & Very strong importance \\
\hline $\mathbf{9}$ & Extreme importance \\
\hline $\mathbf{2 , 4 , 6 , 8}$ & Intermediate values when compromise is needed \\
\hline
\end{tabular}

Step 2: Normalized the pair-wise comparison matrix by using Equation 1

$$
\begin{array}{r}
N_{i j}=\frac{a_{i j}}{\sum_{i=1}^{n} a_{i j}} \ldots \ldots(1) \\
\text { Where, } \mathrm{i}=1,2,3 \ldots \mathrm{n} \\
\mathrm{j}=1,2,3 \ldots \mathrm{n}
\end{array}
$$

Step 3: Find all the row averages of the normalized matrix to find the weightages (priority vector) of all the criteria's i.e. $w_{j}$

Step 4: Find out the consistencies of all the main criteria

a) Multiply the pair-wise comparison matrix with the row average matrix to find out the weighted consistency matrix.

b) Divide each elements of the weighted consistency matrix by their respective priority vector (weightages) to find out the consistencies of each criteria.

c) Find out the averages of all the consistencies to calculate the $\lambda_{\max }$.

Step 5: Checking of consistency [26]

a) Find out the Consistency Index (CI) value by using Equation 2

$$
\mathrm{CI}=\frac{\lambda_{\max }-n}{n-1}
$$

b) Find out the Consistency Ratio (CR) by using Equation 3 .

$$
\mathrm{CR}=\frac{C I}{R I} \ldots \ldots(3)
$$

Where, CI is the Consistency Index, and

$\mathrm{RI}$ is the Randomly Generated Index value which can be obtained from Table 3

Table 3: RI Value (Randomly Generated Index) According to the no of Comparison $n$

\begin{tabular}{|c|c|c|c|c|c|c|c|c|c|c|c|c|}
\hline $\mathbf{n}$ & $\mathbf{1}$ & $\mathbf{2}$ & $\mathbf{3}$ & $\mathbf{4}$ & $\mathbf{5}$ & $\mathbf{6}$ & $\mathbf{7}$ & $\mathbf{8}$ & $\mathbf{9}$ & $\mathbf{1 0}$ & $\mathbf{1 1}$ & $\mathbf{1 2}$ \\
\hline $\mathbf{R I}$ & 0 & 0 & 0.58 & 0.9 & 1.12 & 1.24 & 1.32 & 1.41 & 1.45 & 1.49 & 1.51 & 1.58 \\
\hline
\end{tabular}

c) Now if the CR value is less than 0.1, then it can be concluded that the decision maker judgement for the pair-wise comparison matrix is true and consistent. If the CR value is greater than 0.1 then the pair-wise comparison matrix needs to be altered and then again consistency 
is checked until the CR value is restricted within 0.1 . in this analysis up to $10 \%$ of inconsistency in the decision maker judgements can be allowed, so the CR value needs to be restricted within 0.1 .

Step 6: Prepare an $(m \times n)$ evaluation matrix according to the Hwang and Yoon comparison scale [5] shown in Table 4 . Where, ' $m$ ' is the number of alternatives and ' $n$ ' is the number of criteria.

$$
R\left(m_{i} \times n_{j}\right)=\left[\begin{array}{ccccc}
r_{11} & r_{12} & r_{13} & \cdots & r_{1 n} \\
r_{21} & r_{22} & r_{23} & \cdots & r_{2 n} \\
r_{31} & r_{32} & r_{33} & \cdots & r_{3 n} \\
\ldots & \ldots & \cdots & \cdots & \cdots \\
r_{m 1} & r_{m 2} & r_{m 3} & \cdots & r_{m n}
\end{array}\right]
$$

Table 4: Hwang and Yoon Comparison Scale [5]

\begin{tabular}{|c|c|c|c|c|c|c|}
\hline $\begin{array}{c}\text { Qualitative } \\
\text { estimation }\end{array}$ & Bad & Good & Average & Very Good & Excellent & Type of Criteria \\
\hline $\begin{array}{c}\text { Quantitative } \\
\text { estimation }\end{array}$ & 1 & 3 & 5 & 7 & 9 & MAX \\
\cline { 2 - 7 } & 9 & 7 & 5 & 3 & 1 & MIN \\
\hline
\end{tabular}

Step 7: Normalized the evaluation matrix according to the Equations given in 4 and 5 .

a) For beneficial criteria, i.e. if the criteria is positive (whose larger values is desired)

$$
n_{i j}=\frac{r_{i j}}{r_{j}^{\max }}
$$

Where, $\mathrm{i}=1,2,3 \ldots \mathrm{m}$

$$
\mathrm{j}=1,2,3 \ldots \mathrm{n}
$$

b) For non-beneficial criteria or cost criteria, i.e. if the criteria is negative (whose smaller values is desired)

$$
\begin{aligned}
& \qquad n_{i j}=\frac{r_{j}^{\text {min }}}{r_{i j}} \ldots \ldots \text { (5) } \\
& \text { Where } \mathrm{i}=1,2,3 \ldots \mathrm{m} \\
& \mathrm{j}=1,2,3 \ldots \mathrm{n} \\
& r_{j}^{\text {max }}=\text { Largest number in the column of } \mathrm{j} \\
& r_{j}^{\text {min }}=\text { Smallest number in the column of } \mathrm{j}
\end{aligned}
$$

Step 8: Calculate the Additive Weighted Sum for each of the alternatives by using Equation 6

$$
W_{i}=\sum_{j=1}^{n} w_{j} n_{i j} \ldots \ldots \text { (6) }
$$

Where, $w_{j}=$ Weightages of the criteria

$$
\mathrm{n}_{\mathrm{ij}}=\text { Normalized values }
$$

Now, the alternatives with the highest weighted $\operatorname{sum}\left(\mathrm{W}_{\mathrm{i}}\right)$ is termed as the best alternatives and the alternatives is ranked according to the weighted sum values in the decreasing order.

\section{Methodology}

At first AHP is applied to find out the weightages [29] of the criteria and the consistency is also checked to ensure that the decision maker judgements are consistent. After finding the weightages SAW is applied and the weightages found through AHP is used [30]. All the calculations are shown step by step in details in the next section of this paper.

Table 5 shows a pair-wise comparison matrix which is created according to the Saaty's 9 pair comparison scale shown in Table 2 based on the market survey of 100 computer users. In this matrix each and every criterion is compared [31] with the other criteria to find out the relative importance's among each other. For example, when processor is compared to processor itself, value 1 is allotted in the cell $\mathrm{a}_{11}$ according to Satty's scale [3] which states that 1 stands for the equal importance. Now if processor is compared to brand, 3 is allotted in the cell $a_{12}$ which states that moderate importance according to Saaty's scale, which means 
Mitra et al., Adv. J. Grad. Res.; Vol. 6, Issue 1, pp: 60-68, July 2019

processor seems to be moderately important when compared to brand according to the customer views [1]-[2]. While purchasing a desktop computer the processor quality is somehow matters more to the customers than brand. In this way this pair-wise comparison matrix is formed based on the relative choices and preferences of the buyers.

Table 5: Pair-Wise Comparison Matrix

\begin{tabular}{|c|c|c|c|c|c|}
\hline Comparisons & Processor & Brand & Screen Size & $\begin{array}{c}\text { Hard Disk } \\
\text { Capacity }\end{array}$ & RAM \\
\hline Processor & 1 & 3 & 5 & 7 & 5 \\
\hline Brand & $1 / 3$ & 1 & 6 & 3 & 2 \\
\hline Screen Size & $1 / 5$ & $1 / 6$ & 1 & $1 / 3$ & $1 / 3$ \\
\hline Hard Disk Capacity & $1 / 7$ & $1 / 3$ & 3 & 1 & $1 / 3$ \\
\hline RAM & $1 / 5$ & $1 / 2$ & 3 & 3 & 1 \\
\hline Total & 1.87619048 & 5 & 18 & 14.33333333 & 8.66666667 \\
\hline
\end{tabular}

The pair-wise comparison matrix is normalized by dividing each elements of Table 5 by their respective column sum as given by Equation 1 thus obtaining the normalized matrix as shown in Table 6. Then calculating all the row averages of the normalized matrix to find out the weightages of the criteria's as shown in the Table 6 .

Table 6: Normalization of the Pair-Wise Comparison Matrix

\begin{tabular}{|c|c|c|c|c|c|c|c|}
\hline Comparisons & Processor & Brand & Screen Size & $\begin{array}{c}\text { Hard Disk } \\
\text { Capacity }\end{array}$ & RAM & $\begin{array}{c}\text { Row } \\
\text { Average }\end{array}$ & Weight \% \\
\hline Processor & 0.53299492 & 0.6 & 0.27777778 & 0.48837209 & 0.57692308 & 0.49521357 & 49.52135743 \\
\hline Brand & 0.17766497 & 0.2 & 0.33333333 & 0.20930233 & 0.23076923 & 0.23021397 & 23.02139729 \\
\hline Screen Size & 0.10659898 & 0.033333333 & 0.05555556 & 0.02325581 & 0.03846154 & 0.05144105 & 5.14410452 \\
\hline $\begin{array}{c}\text { Hard Disk } \\
\text { Capacity }\end{array}$ & 0.07614213 & 0.06666667 & 0.16666667 & 0.06976744 & 0.03846154 & 0.08354089 & 8.35408891 \\
\hline RAM & 0.10659898 & 0.1 & 0.16666667 & 0.20930233 & 0.11538462 & 0.13959052 & 13.95905185 \\
\hline Total & 1 & 1 & 1 & 1 & 1 & 1 & 100 \\
\hline
\end{tabular}

\subsection{Calculation of Consistency}

$\left[\begin{array}{ccccc}1 & 3 & 5 & 7 & 5 \\ 1 / 3 & 1 & 6 & 3 & 2 \\ 1 / 5 & 1 / 6 & 1 & 1 / 3 & 1 / 3 \\ 1 / 7 & 1 / 3 & 3 & 1 & 1 / 3 \\ 1 / 5 & 1 / 2 & 3 & 3 & 1\end{array}\right] \times\left[\begin{array}{l}0.49521357 \\ 0.23021397 \\ 0.05144105 \\ 0.08354089 \\ 0.13959052\end{array}\right]=\left[\begin{array}{l}2.72579954 \\ 1.23373514 \\ 0.26322989 \\ 0.43187698 \\ 0.75868602\end{array}\right]$
$\left\{\begin{array}{l}2.72579954 / 0.49521357 \\ 1.23373514 / 0.23021397 \\ 0.26322989 / 0.05144105 \\ 0.43187698 / 0.08354089 \\ 0.75868602 / 0.13959052\end{array}\right\}$
$=\left\{\begin{array}{l}5.50429083 \\ 5.35908018 \\ 5.11711786 \\ 5.16964793 \\ 5.43508278\end{array}\right\}$

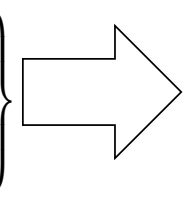
$\left\|\begin{array}{c}\text { Processor } \\ \text { Brand } \\ \text { Screen Size } \\ \text { Hard Disk Capacity } \\ \text { RAM }\end{array}\right\|$

The consistency is calculated for every criterion as shown above. Now finding the average consistency $\lambda_{\max }$. $\frac{5.50429083+5.35908018+5.11711786+5.16964793+5.43508278}{5}=\frac{26.58521959}{5}=5.31704392$

Average Consistency $\left(\lambda_{\max }\right)=5.31704392$

The pair-wise comparison matrix is multiplied with the row average matrix to find out the weighted consistency of the alternatives, then all the elements of the weighted consistency matrix [32] is divided by their respective priority vector to find out the consistency of each alternatives. Then finding the averages of all the consistency to find out the average consistency $\lambda_{\max }$. 
Consistency Index (CI) value is calculated by using Equation 2 as follows:

$$
\begin{gathered}
\mathrm{CI}=\frac{(5.31704392-5)}{(5-1)}=\frac{0.31704392}{4}=0.07926098 \\
\mathrm{CR}=\mathrm{CI} / \mathrm{RI}=>\frac{0.07926098}{1.12}=0.07076873
\end{gathered}
$$

Here RI value is 1.12 taken from the Table 3 . In this case there are 5 comparisons so, $\mathrm{n}=5$

Since, the CR value is less than 0.1 , i.e. $0.07076873 \leq 0.1$ thus it can be concluded that the decision maker judgements for the pair-wise comparison matrix is consistent and well within the limit (i.e. 7\%). Now SAW can be applied to the above method because all the weightages of the criteria have been calculated and the consistency is also checked which is well within the limit (Table 7).

Table 7: Consistency Check

\begin{tabular}{|l|l|}
\hline No of Comparisons $(\mathrm{n})$ & $\mathbf{5}$ \\
\hline Average Consistency $\left(\lambda_{\max }\right)$ & 5.31704392 \\
\hline Consistency Index $(\mathrm{CI})$ & 0.07926098 \\
\hline Randomly Generated Consistency Index (RI) & 1.12 \\
\hline Consistency Ratio $(\mathrm{CR})$ & 0.07076873 \\
\hline Consistent & YES \\
\hline
\end{tabular}

Table 8: Evaluation Matrix

\begin{tabular}{|c|c|c|c|c|c|}
\hline Models & Processor & Brand & Screen Size & $\begin{array}{c}\text { Hard Disk } \\
\text { Capacity }\end{array}$ & RAM \\
\hline Model 1 & 4 & 7 & 1 & 1 & 3 \\
\hline Model 2 & 4 & 5 & 3 & 5 & 7 \\
\hline Model 3 & 7 & 4 & 9 & 9 & 7 \\
\hline Model 4 & 3 & 9 & 9 & 5 & 2 \\
\hline Model 5 & 7 & 1 & 5 & 5 & 7 \\
\hline
\end{tabular}

Table 8 shows the evaluation matrix which is created according to the Hwang and Yoon comparison scale based on the choices and preferences of the customers [33]. From Table 1 it can be seen that there are 3 types of processor that are taken into consideration (i.e. I3, I5, I7), so from the market survey of the buyers it is found that the demand of I5 processor is more followed by I3 and I7. So, the models with I5 processor (i.e. Model 3 and Model 5) is allotted with the maximum value i.e. 7 under the processor column followed by I7 (i.e. 4) and I3 (i.e. 3). Similarly, the most preferable brand among the computer users is found to be HP followed by Samsung and Dell, so HP is allotted the maximum value i.e. 9 followed by Samsung (i.e. 7) and Dell (i.e. 5) under the brand column. Likewise, all the values are placed in all the cells thus creating the evaluation matrix as shown in Table 8 based on the choices of the customers and buyers [34]. Although the magnitude of the values allotted in all the cells depends on the decision maker. This evaluation matrix is also known as the decision matrix [1].

All the criteria considered for this analysis is beneficial in nature that means whose larger values is desired. For example, higher the processor value it would be more preferable and same for the other criteria also, higher the RAM or hard disk capacity then it will be more preferable by the customers. So, by using Equation 4 normalization is done and shown in Table 9. The additive weightage is calculated for all the alternatives by using the Equation 6 and similarly all the weightages \% is also calculated as shown in Table 10. The calculation for Model 1 is shown in detail below.

For Model 1, the calculation of simple additive weightage is as follows:

$$
\begin{aligned}
W_{l}= & (0.49521357 \times 0.57142857)+(0.23021397 \times 0.777777778)+(0.05144104 \times 0.11111111)+ \\
& (0.08354089 \times 0.11111111)+(0.13959052 \times 0.42857143)=0.53685700 \text { or } 53.685700 \%
\end{aligned}
$$


Mitra et al., Adv. J. Grad. Res.; Vol. 6, Issue 1, pp: 60-68, July 2019

Similarly, all the additive weightages for all the models is found out in the same way as shown above for Model 1. All the calculated weightages and their percentages is shown in Table 10.

Table 9: Normalization of the Evaluation Matrix

\begin{tabular}{|c|c|c|c|c|c|}
\hline Weights $\left(w_{i}\right)$ & 0.49521357 & 0.23021397 & 0.05144104 & 0.08354089 & 0.13959052 \\
\hline Models & Processor & Brand & Screen Size & $\begin{array}{c}\text { Hard Disk } \\
\text { Capacity }\end{array}$ & RAM \\
\hline Model 1 & 0.57142857 & 0.77777777 & 0.11111111 & 0.11111111 & 0.42857143 \\
\hline Model 2 & 0.57142857 & 0.55555556 & 0.33333333 & 0.55555556 & 1 \\
\hline Model 3 & 1 & 0.44444444 & 1 & 1 & 1 \\
\hline Model 4 & 0.42857143 & 1 & 1 & 0.55555556 & 0.28571429 \\
\hline Model 5 & 1 & 0.11111111 & 0.55555556 & 0.55555556 & 1 \\
\hline
\end{tabular}

Table 10: Additive Weightage Summation

\begin{tabular}{|c|c|c|}
\hline Models & Simple Additive Weightage & Weightage \% \\
\hline Model 1 & 0.53685700 & 53.685700 \\
\hline Model 2 & 0.61402498 & 61.402498 \\
\hline Model 3 & 0.87210335 & 87.210335 \\
\hline Model 4 & 0.58018402 & 58.018402 \\
\hline Model 5 & 0.73537339 & 73.537339 \\
\hline
\end{tabular}

\section{$5 \quad$ Results and Discussion}

Table 10 shows the weightages \% of all the alternatives. After calculating the Simple Additive Weightages of all the alternatives, Model 3 is found to obtain the highest weightages $\%$ i.e. $87.210335 \%$ followed by Model 5, Model 2, Model 4 and Model 1. The ranking order of the computer models is shown in Table 11 according to the decreasing order of the weightage $\%$.

Table 11: Ranking of the Desktop Computer Models

\begin{tabular}{|c|c|c|}
\hline Models & Weightage \% & Ranking \\
\hline Model 1 & 53.68 & Rank 5 \\
\hline Model 2 & 61.40 & Rank 3 \\
\hline Model 3 & 87.21 & Rank 1 \\
\hline Model 4 & 58.01 & Rank 4 \\
\hline Model 5 & 73.54 & Rank 2 \\
\hline
\end{tabular}

The ranking of the models would be Model $3>$ Model $5>$ Model $2>$ Model $4>$ Model 1 respectively.

\section{Conclusion}

From this analysis it can be concluded that the Model 3 is the best preferable model based on the market views of the customers. This methodology provides a guideline to the students while purchasing a computer. The electronic stores and as well as the online shopping websites who sold computers can also be benefitted by this methodology. Since this paper provides a guideline about which of the desktop computer model is in demand right now in the market so that they can keep that model in adequate quantity to meet the needs of the customers. The same problems can also be solved by applying other MCDM methodology such as AHP, TOPSIS, FUZZY-AHP, FUZZY-SAW etc. This MCDM methodologies also helps the desktop manufacturing companies to shape their future business strategies based on the present market demand of the customers. 


\section{Declarations}

\subsection{Acknowledgements}

We are ever grateful to the participants for cooperating and giving us their valuable time for the market survey we have done.

\subsection{Funding Source}

None, the authors didn't receive any kind payments or funding's from any sources.

\subsection{Competing Interests}

The corresponding author confirms on behalf of all authors that there has been no conflict of interest in this publication. The objectives of this research article neither have any intention to promote any kind of computer brand mentioned in this article nor to degrade any computer manufacturing companies. This whole analysis is completely based on the market survey and the reviews of the desktop users.

\subsection{Informed Consent}

Consent from all respondent were taken by informing them purpose of this survey.

\section{How to Cite this Article:}

S. Mitra and S. Goswami, "Application of Simple Average Weighting Optimization Method in the Selection of Best Desktop Computer Model”, Adv. J. Grad. Res., vol. 6, no. 1, pp. 60-68, Jul. 2019. doi: 10.21467/ajgr.6.1.60-68

\section{References}

[1] S. Mitra and S. S. Goswami "Selection of the desktop computer model by AHP-TOPSIS hybrid MCDM methodology," International Journal of Research and Analytical Reviews (IJRAR), vol. 6, no. 1, pp. 784-790, 2019.

[2] S. Mitra and S. S. Goswami "Application of integrated MCDM technique (AHP-SAW) for the selection of best laptop computer model," International Journal for Research in Engineering Application \& Management (IJREAM), vol. 4, no. 12, pp. 1-6, Mar 2019.

[3] T. L. Saaty "The analytic hierarchy process," New York: McGraw-Hill, 1980.

[4] R. W. Saaty "The analytic hierarchy process - what it is and how it is used," Mathematical Modelling, Elsevier, vol. 9, no. 3-5, pp. 161-176, 1987.

[5] C. L. Hwang and K. Yoon "Multiple Attributes Decision Making Methods and Applications", Berlin: Springer, 1981.

[6] R. Karim and C. L Karmaker "Machine Selection by AHP and TOPSIS Methods," American Journal of Industrial Engineering, vol. 4, no. 1, pp. 7-13, 2016.

[7] M. Behzadian, R. B. Kazemzadeh, A. Albadvi, and M. Aghdasi "PROMETHEE: A Comprehensive Literature Review on Methodologies and Applications," European Journal of Operational Research, Elsevier, vol. 200, no. 1, pp. 198-215, Jan 2010.

[8] M. B. Ayhan "A Fuzzy AHP Approach for Supplier Selection Problem: A Case Study in a Gearmotor Company," International Journal of Managing Value and Supply Chains (IJMVSC), vol. 4, no. 3, pp. 11-23, Sept 2013.

[9] S. Mitra and S. Kundu "Application of TOPSIS for Best Domestic Refrigerator Selection," International Journal of Research and Analytical Reviews, vol. 5, no. 3, pp. 226-231, 2018.

[10] S. Mitra and S. Kundu "Application of Analytic Hierarchy Process for Domestic Refrigerator Selection," International Journal of Emerging Technologies in Engineering Research, vol. 5, no. 12, pp. 126-132, 2017.

[11] S. A. Sahaaya Arul Mary and G. Suganya "Multi-Criteria Decision Making Using ELECTRE," Scientific Research Publishing, pp. 1009-1019, 2016.

[12] L. Abdullah and C. W. Rabiatul Adawiyah "Simple Additive Weighting Methods of Multi criteria Decision Making and Applications: A Decade Review," International Journal of Information Processing and Management (IJIPM), vol. 5, no. 1, pp. 39-49, Feb 2014.

[13] S. D. Pohekar and M. Ramachandran "Application of multi-criteria decision making to sustainable energy planning-A review," Renewable and Sustainable Energy Reviews, vol. 8, no. 4, pp. 365-381, Jan 2004.

[14] A. Chauhan and R. Vaish "A Comparative Study on Decision Making Methods with Interval Data," Journal of Computational Engineering, vol. 2014, Article ID 793074, 10 pages, 2014.

[15] R. Abu Taha "Multi criteria Applications in Renewable Enegy Analaysis: A Literature Review," Proceedings of Technology Management of in the Energy Smart World, pp. 1-8, 2011.

[16] W. Ho, X. Xu and P. K. Dey "Multi-criteria decision-making approaches for supplier evaluation and selection: A literature review," European Journal of Operational Research, vol. 202, no. 1, pp. 16- 24, 2010.

[17] P. Agarwal, M. Sahai, V. Mishra, M. Bag and V. Singh "A review of multi-criteria decision-making techniques for supplier evaluation and selection," International Journal of Industrial Engineering Computations, vol. 2, no. 4, pp. 801-810, 2011.

[18] A. Afshari, M. Mojaheed and R. M. Yusuff "Simple Additive Weighting Approach to Personnel Selection Problem," International Journal of Innovation, Management and Technology (IJIMT), vol. 1, no. 5, pp. 511-515, Dec 2010.

[19] C. Carlsson and R. Fuller "Fuzzy multiple criteria decision making: Recent developments," Fuzzy Sets and Systems, vol. 78, no. 2, pp. 139-153, Mar 1996. 
Mitra et al., Adv. J. Grad. Res.; Vol. 6, Issue 1, pp: 60-68, July 2019

[20] L. A. Zadeh "Fuzzy sets," Information and Control, vol. 8, no. 3, pp. 338-353, June 1965.

[21] A. Keufmann and M. M. Gupta "Introduction to Fuzzy Arithmetic: Theory and Application," New York: Van Nostrand Reinhold, 1991.

[22] Z. Li, V. Kecman and A. Ichikawa "Fuzzified neural network based on fuzzy number operations," Fuzzy Sets and Systems, Elsevier, vol. 130, no. 3, pp. 291-304, Sept 2002.

[23] W. Deni, O. Sudana and A. Sasmita "Analysis and Implementation Fuzzy Multi-Attribute Decision Making SAW Method for Selection of High Achieving Students in Faculty Level," International Journal of Computer Science, vol. 10, no, 1, pp. 674-680, Jan 2013.

[24] S. Gupta and A. Gupta "A Fuzzy Multi Criteria Decision Making Approach for Vendor Evaluation in a Supply Chain," Interscience Management Review, vol. 2, no. 3, pp. 10-16, 2012.

[25] M. Kumar, P. Jayaswal, and K. Kushwah "Exploring Fuzzy SAW Method for Maintenance Strategy Selection Problem of Material Handling Equipment," International Journal of Current Engineering and Technology, vol. 3, no. 2, pp. 600-605, 2013.

[26] R. A. ZeinEldin and B. M. Abdullah "Comparing two multi-criteria approaches to investigate their ability in measuring efficiency," International Journal for Modern Trends in Science and Technology, vol. 3, no. 2, pp. 52-56, Feb 2017.

[27] K. Kabassi "Fuzzy Simple Additive Weighting for Evaluating a Personalised Geographical Information System," New Directions in Intelligent Interactive Multimedia Systems and Services-2, Studies in Computational Intelligence, vol. 226, pp. 275-284, 2009.

[28] A. Kumar, B. Sah, A. R. Singh, Y. Deng, X. He, P. Kumar, R. C. Bansal "A review of multi criteria decision making (MCDM) towards sustainable renewable energy development," Renewable and Sustainable Energy Reviews, Elsevier, vol. 69, pp. 596-609, Mar 2017.

[29] E. K. Zavadskas, J. Antucheviciene, Z. Turkis and H. Adeli "Hybrid multiple-criteria decision-making methods: A review of applications in engineering," Sharif University of Technology, vol. 23, no. 1, pp. 1-20, Feb 2016.

[30] S. Alshehri "Multicriteria Decision Making (MCDM) Methods for Ranking Estimation Techniques in Extreme Programming," Engineering, Technology \& Applied Science Research, vol. 8, no. 3, pp. 3073-3078, 2018.

[31] D. Yu, W. Wang, W. Zhang and S. Zhang "A bibliometric analysis of research on multiple criteria decision making," Current Science, vol. 114, no. 4, pp. 747-758, Feb 2018.

[32] F. Sitorus, J. J. Cilliers and P. R. Brito-Parada "Multi-criteria decision making for the choice problem in mining and mineral processing: Applications and trends," Expert Systems with Applications, Elsevier, vol. 121, pp. 393-417, May 2019.

[33] R. F. de Farias Aires and L. Ferreira "The rank reversal problem in multi-criteria decision making: A literature review," Pesquisa Operacional, vol. 38, no. 2, May/Aug 2018.

[34] T. L. Saaty "Decision making with the analytic hierarchy process," International Journal of Services Sciences, vol. 1, no. 1, 2008.

Publish your research article in AIJR journals-

$\checkmark$ Online Submission and Tracking

$\checkmark$ Peer-Reviewed

$\checkmark$ Rapid decision

$\checkmark \quad$ Immediate Publication after acceptance

$\checkmark \quad$ Articles freely available online

$\checkmark$ Retain full copyright of your article.

Submit your article at journals.aijr.in
Publish your books with AIJR publisher-

$\checkmark \quad$ Publish with ISBN and DOI.

$\checkmark$ Publish Thesis/Dissertation as Monograph.

$\checkmark$ Publish Book Monograph.

$\checkmark$ Publish Edited Volume/ Book.

$\checkmark$ Publish Conference Proceedings

$\checkmark$ Retain full copyright of your books.

Submit your manuscript at books.aijr.org 